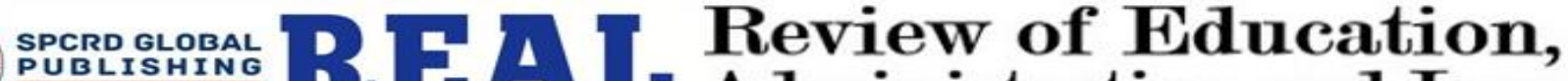 Administration and Law \\ Journal homepage: http://real.spcrd.org ISSN (Print): 2708-1788

\section{Impact of Motivational Factors on Motivation of Police Force: A Case of Project of Punjab Police}

\author{
${ }^{a}$ Masab Bin Shahid, ${ }^{b}$ Aftab Ul Haq, ${ }^{c}$ Shahid Iqbal, ${ }^{d}$ Anum Munir \\ a Police Communication Officer Punjab Safe Cities Authority, Lahore, Pakistan \\ Email: masababbasi87@gmail.com \\ ${ }^{\mathrm{b}}$ MS Project Management, Bahria University, Lahore Campus, Pakistan \\ Email:aftabulhaqo62@gmail.com \\ ${ }^{c}$ Assistant Professor, Management Studies Department, Bahria University, Islamabad Campus, Pakistan \\ Email: siqbal.buic@bahria.edu.pk \\ ${ }^{\mathrm{d}}$ MS Engineering Management, (CASE), UET Taxila, Pakistan \\ Email:anumhussain61@gmail.com
}

\begin{tabular}{l}
\hline ARTICLE DETAILS \\
\hline History: \\
Accepted 15 Dec 2020 \\
Available Online 31 Dec 2020 \\
\hline Keywords: \\
Motivation; Intrinsic Motivation; \\
Extrinsic Motivation; Motivators; \\
Project Management; Hygiene \\
Factors
\end{tabular}

JEL Classification:

J23,J29, J53

DOI: $10.47067 /$ real.v3i3.95

\section{ABSTRACT}

The purpose of this study was to identify the factors that motivate security force personals at work and then study the impact of these identified factors on Motivation of Specialized Unit of Punjab Police Personals. The motivational factors were identified through interviews and after comparison with literature eight motivational factors were identified as independent variable with Motivation as a dependent variable. In order to study the impact of identified motivational factors on motivation of employees, a survey method was used. Questionnaires comprising of five point Likert scale questions were distributed among 306 respondents i.e. Security Force Personals. The results revealed that motivational factors Working Conditions, Career Growth Opportunities, Peer/Fellow Relationship, Salary and Organizational Policies were found to have a significant impact on motivation of Police Force. Whereas factors like recognition, work itself \& supervisor role were not proved to be significant. From this study it can be concluded that motivational factors tend to differ in different job settings and careful consideration should be given to the factors that motivate employees in order to enhance their performance. The current study can prove to be a valuable input for policy makers of Police Department and help them understand the motivational needs of employees in different projects of Punjab police.

(C) 2020 The authors. Published by SPCRD Global Publishing. This is an open access article under the Creative Commons AttributionNonCommercial 4.0

Corresponding author's email address: masababbasi87@gmail.com

\section{Introduction}

People are very important component of any project or organization. If people are managed effectively, it results in improving overall project efficiency and helps in achievement of goals. 
According to (Muhammad Asad Khan, 2020), employee's satisfaction results in better organizational performance (Iqbal et al. , 2020). This satisfaction results in motivation of employees and improves their overall efficiency (AlKahtani et al., 2020). If we consider police force, there too employee's management has a critical role to play. Today, the nature of Police work has certainly changed and Police is moving from traditional work of maintaining law and order to a more innovative and specialized organization. Punjab Police for instance has been divided into various specialized units like Counter Terrorism Department (CTD), Special Protection Unit (SPU) and Special Branch etc. Therefore managing such a diverse human resource deems a better insight into the issues related to personal management.

In Pakistan, police force has laid tremendous sacrifices in coping the menace of terrorism but Police Force is under an immense criticism by media and other sections of society. The major reason behind this criticism is the lack of professionalism and below standard performance. According to a study by (Farhat Ullah S. H., 2016), the image of police force in Pakistan is damaged due to lack of professionalism, lack of training and low salaries. Similarly a report of United States Institute of Peace by (Pervez, 2014) concludes lack of motivation to be a factor responsible for inefficient performance of Police Force. In order to manage the police force effectively, it is extremely important to motivate police force. According to a study by (Were M. Susan, 2012) on Police Force in Kenya, motivation of police force has a strong influence on performance of Police Force. The study also suggests government to ensure motivation of police force for improved performance and service delivery. Therefore we can conclude that motivation of Police Force is one of the key factors in improving service delivery and overall performance.

The population under study in this research paper is a specialized unit of Punjab Police. This unit is designated for the security of foreigners working on different CPEC Projects. CPEC has an immense importance for Pakistan and it is considered to be the engine of growth and investment. In order to ensure efficient performance of the force, it is important to keep them motivated. The current research serves the purpose by identifying the motivational factors of the force and then studying the impact of these factors on motivation of force. The factors that are ranked highest based on analysis of data gathered through survey may serve as a valuable input for policy makers. Apart from this, other reason of conducting this research is to fill the research gap that exists. There has been a limited research on police force worldwide generally and in Pakistan specifically. According to a study by (Farhat Ullah I. A., 2016) there is limited research on motivational aspect of police training. Therefore this study proves to be a valuable input in bridging the research gap.

\section{Literature Review}

\subsection{Motivation}

Motivation is defined as a stimulus that makes someone to do something. Humans in general do need a stimulus or a reason to do something. Motivation has been defined by (Whisenand, 1998) as the psychological force that exists within an individual and determines his behavior in an organization/project, his effort and way of tackling hurdles. Saraswathi (2011) also supported the definition discussed previously. He defines motivation as the willingness to exert effort towards the organizational/project goals. The effort exerted is used to satisfy some needs. (Shafighi, 2013), In their study on Housing Foundation employees define motivation as energizing factors and main cause for making people to act.

Motivation can be classified into intrinsic motivation and extrinsic motivation. Intrinsic motivation is basically doing something because it is interesting while extrinsic motivation is doing of 
an activity because of some external stimuli. Therefore it is extremely important for organizations to maintain a balance between both intrinsic and extrinsic factors to motivate employees.

\subsection{Theories of Motivation}

Theories of motivation are broadly categorized into content theories and process theories. Content theories explain motivation in terms of needs and tend to answer "What" part of motivation. Maslow's Hierarchy of Needs (1943), Herzberg's Two Factor Theory (1959), (McClelland, 1961) and (Alderfer, 1969)are the most common content theories.

(Maslow, 1943), believes there is a hierarchy of needs and all humans are motivated by satisfying these needs. In contrast to Maslow's hierarchy of needs, (Frederick Herzberg, 1959) found that certain factors are related to job satisfaction (Motivators) and others related to job dissatisfaction (Hygiene Factors). Motivators if present lead to Job Satisfaction and tend to be intrinsic in nature. In contrast Hygiene Factors were extrinsic or external factors and their presence prevents job dissatisfaction.

(Alderfer, 1969) ERG Theory bifurcated the needs into Existence, Relatedness and Growth needs. In contrary to (Maslow, 1943), (Alderfer, 1969) denies hierarchy of needs. He further argues that if individual's lower level needs are satisfied then he quests for higher level needs. (McClelland, 1961) Leaner need theory is another content theory of motivation. He argues that individuals are motivated by three needs i.e. (need for achievement, need for power and need for affiliation).

In contrast process theories of motivation tend to deal with "How" part of motivation. (H.Vroom, 1964) Expectancy Theory is among the common process theories. Process theories tend to explain how motivation is caused, maintained and ceased while content theories attempt to identify specific factors which initiate, maintain and reduce motivation.

\subsection{Motivational Factors}

One of the purpose of this research paper is the identification of factors that motivate police force. As there is a scarcity of research on police force not only in Pakistan but also worldwide and what motivates people differs, therefore in order to identify the factors that motivate police force interviews were conducted from respondents. During interviews questions were asked from respondents about the factors that motivate them. As a result of interviews the factors identified are:

- Working Conditions

- Career Growth Opportunities

- Peer/Fellow Relationships

- Work Itself

- Recognition

- Supervisor Role

- Salary

- Organizational Policies

\subsection{Hypothesis Development and Research Model}

2.4.1 Working Conditions and Motivation

Working conditions correspond to the physical conditions at workplace. According to ILO (International Labor Organization), working conditions cover a broad range of work related topics and issues such as working hours, rewards and physical conditions. Working conditions are a lower level 
need according to Maslow's Theory and a hygiene factor according to Herzberg's Theory. According to (Joshi, 2013), it is the responsibility of management to create motivating work environment. According to a senior Police Officer Dr. Syed Kaleem Imam (2011), working conditions affect motivational level of police force. Following Hypothesis has been developed:

H1: Working conditions have an impact on motivation of employees

\subsubsection{Career Growth Opportunities and Motivation}

Career growth opportunities correspond to chances of promotion in a job setting. A proper job structure will ensure job security which will help employee focus on his job and perform his duty efficiently. Career Growth opportunity one of the detriment of motivation was found to have a significant impact on performance of employees (Shafighi, 2013). A study on Malaysian service workers by (Muhammad Saeed Aarabi, 2013) also support above findings. According to Maslow's theory presence of career growth opportunities keep employees motivated, similarly (Frederick Herzberg, 1959) also consider it a motivator. Following Hypothesis has been developed:

H2: Career growth opportunities have an impact on motivation of employees

\subsubsection{Peer/Fellow Relationship and Motivation}

Humans being a social animal have to interact with others. This includes personal relationship and working relationships between the workers and higher command. (Maslow, 1943), considers relationships as lower level need, (Frederick Herzberg, 1959) termed it as a Hygiene Factor but literature shows that interpersonal relationships have an impact on Motivation. A study on Indian Police Force by (Gupta, 2002), reports interpersonal relationships to be an important factor in motivation of police force. The study further reports that officers consider it more important compared to lower ranks. Similarly a study by (Sommerfeldt, 2010) on Queensland Police also reports similar findings. Following Hypothesis has been developed:

H3: Peer/fellow relationships have an impact on motivation of employees

\subsubsection{Work Itself \& and Motivation}

This includes events related to tasks whether tasks are too interesting, too boring. The work can be made interesting to motivate employees. (Herzberg, 2003), says job enrichment is all about making the work or job interesting, removing unnecessary control and brainstorming with the employees. According to a study by (Shalini Bhatia, 2014) on Indian Doctors, interesting work was among top motivational factors. The work of police involves a lot of stress so it's extremely important that the work they perform should be interesting. A study by (Saraswathi, 2011) also supports similar findings. Following hypothesis has been developed:

H4: Work itself has an impact on motivation of employees.

\subsubsection{Recognition \& and Motivation}

Recognition means to appreciate employees' work. Recognition includes praise or rewards for reaching specific goals. Police force in Pakistan performs a lot of good but that good work is rarely appreciated. This lack of appreciation results in demotivation of police ranks. A study on Indian Doctors by (Shalini Bhatia, 2014) also proves recognition to be the top motivational factor. Similarly a study by (Saraswathi, 2011), IT Sector employees also support results of (Shalini Bhatia, 2014) study. A study on Queensland Police by (Sommerfeldt, 2010) also ranks recognition to be a top motivational factor. According to (Maslow, 1943), recognition is among higher level needs, whereas (Frederick Herzberg, 1959) also considers it a motivational factor. Following hypothesis has been developed:

H5: Recognition has an impact on motivation of employees. 


\subsubsection{Supervisor's Role and Motivation}

In any organization or project, motivating employees is one of the key responsibilities of supervisor. Police force has a bureaucratic style of command so it's extremely important that police leader should motivate employees, should appreciate their good work, develop relations and try to bridge the gap between operational force and police higher command. According to a study by (Abdul Qayyum Chaudry, 2012), leadership styles have an impact on motivation of employees. A study on police force by (Lokesh, 2016), also reports supervision to be the most important factor that result in job satisfaction employees. (Maslow, 1943) considers supervisor role to be a low-level need that should be satisfied to keep employees motivated whereas (Frederick Herzberg, 1959) considers supervision to be a hygiene factor. Following Hypothesis has been developed:

H6: Supervisor's role has an impact on motivation of employees.

\subsubsection{Salary and Motivation}

Adequate salary certainly has a role in motivating employees. When employees are paid well, then are free from their personal issues and can dedicate full attention to work. If we consider police force in Pakistan, it is characterized by low salaries and it is probably the least paid job compared to volume and complexity of work. A study on Indian Police force by (Gupta, 2002) finds salary to be a motivational factor. Adequate salary is also reported to be top motivational factors by Indian Government Doctors (Shalini Bhatia, 2014). Higher salaries can have a significant impact on motivation of police force (Imam, 2011). Both (Maslow, 1943) and (Frederick Herzberg, 1959) consider salary to have an impact on motivation of employees. Following Hypothesis has been developed:

H7: Salary has an impact on motivation of employees.

\subsubsection{Organizational Policies and Motivation}

Policies like HR (Human Resource) Policy, Appraisal Policy and Health Policy etc have an impact on employees' motivation. The organizational policies create an overall environment which can motivate employees to give their best at work. (Maslow, 1943), considers organizational policies among lower level needs whereas (Frederick Herzberg, 1959) also term it as a hygiene factor but both agree that organizational policies have an impact on motivation of employees. For law enforcement agencies, organizations certainly matter a lot and they are source of pride. Working conditions, supervision and management are reported to be the top motivational factors in a study on health workers in Asia (Haider \& Kayani, 2020). Similarly, a study by (Saraswathi, 2011) also reports similar findings. Organizational policies create an overall environment that keep employees motivated thus preventing job burnout ( (Asif Sajjad, 2013). Following Hypothesis has been developed:

H8: Organizational Policies have an impact on Motivation of Employees. 


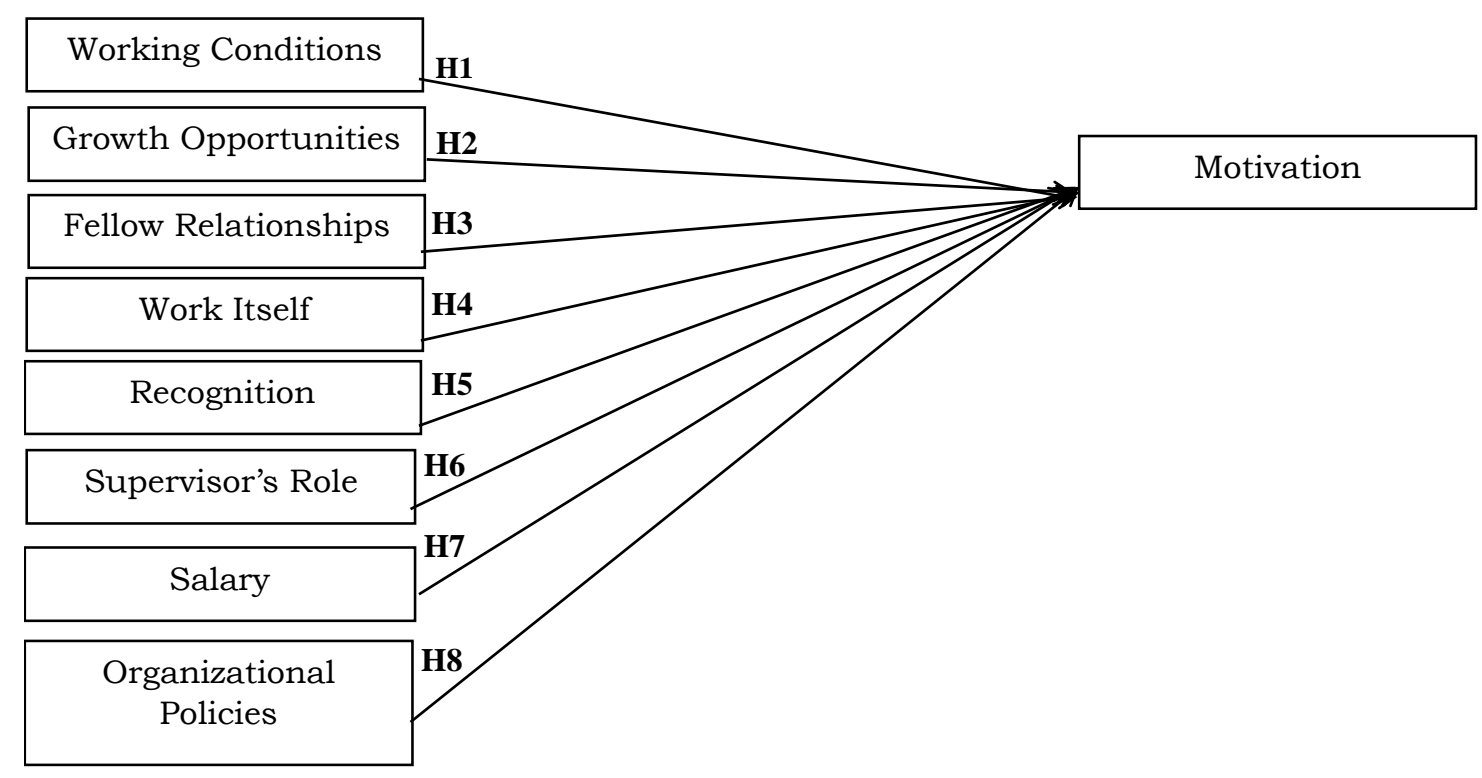

FIGURE 1: HYPOTHESIZED MODEL

\section{Research Methodology}

\subsection{Data Collection Technique}

For the identification of motivational factors interviews were conducted from security force personals at regional headquarters. In order to study impact of motivational factors on motivation of employee's questionnaires were distributed among 306 police force personals at various installations. Survey method helps to gather reliable and accurate data in a short span of time.

\subsection{Measure}

5 point Likert scale comprising of responses from Strongly Disagree to Strongly Agree was used. The measurement scale for each variable was adapted from scales previously used in different studies.

\subsection{Working Conditions}

The total number of items related to this variable is 5 . All 5 items related to Working Conditions are adapted from the scale used by (Sommerfeldt, 2010) on police force in Australia.

\subsection{Career Growth Opportunities}

The total number of items related to this variable is 4 . All 4 items related to Career Growth Opportunities are adapted from the scale used by (Sommerfeldt, 2010) in his study on police force in Australia.

\subsection{Peer/ Fellow Relationships}

The total number of items related to this variable is 5. 2 items related to Peer/ Fellow Relationships are adapted from the scale used by (Sommerfeldt, 2010) in his study on police force in Australia. 2 items are adapted from the scale used in a study by (Altindis, 2011) and 1 item is adapted from Minnesota Questionnaire developed by (David J. Weiss, 1967)

\subsection{Work Itself}

The total number of items related to this variable is 5.4 items related to Work Itself are adapted from the scale used by (Sommerfeldt, 2010) in his study on police force in Australia. 1 item is adapted from the scale used by (Altindis, 2011) in her study. 


\subsection{Supervisor's Role}

The total number of items related to this variable is 4.2 items related to Work Itself are adapted from the scale used by (Sommerfeldt, 2010) in his study on police force in Australia. 2 items are adapted from the scale used by (Altindis, 2011) in her study and 1 item is adapted from Minnesota Questionnaire developed by (David J. Weiss, 1967).

\subsection{Salary}

The total number of items related to this variable is 4.2 items related to Salary are adapted from the scale used by (Sommerfeldt, 2010) in his study on police force in Australia. 1 item is adapted from the scale used by (Altindis, 2011) in her study and 1 item is adapted from Minnesota Questionnaire developed by (David J. Weiss, 1967).

\subsection{Organizational Policies}

The total number of items related to this variable is 4.2 items related to Organizational Policies are adapted from the scale used by (Sommerfeldt, 2010) in his study on police force in Australia. 2 items are adapted from Minnesota Questionnaire developed by (David J. Weiss, 1967)

\subsection{Motivation}

The total number of items related to this variable is 8 . All 8 items related to Working Conditions are adapted from the scale used by (Sommerfeldt, 2010) on police force in Australia.

\section{Data Analysis and Results:}

Data analysis was done using SPSS 23.o. First of all demographic analysis was done. After the Demographic Analysis, the results of reliability analysis are discussed. Then the results of correlational analysis are discussed. After that the eight hypothesis developed are tested using Multiple Linear Regression Analysis.

\subsection{Demographic Statistics}

Demographic statistics shows the age, rank and educational qualification of respondents. 86.6\% of total respondents i.e. 265 are aged less than 25 Years, the respondents aged between 26-35 Years is 9.5\% i.e. (29 respondents) \& the respondents aged above 36 Years are 3.9\% i.e. 12 respondents. 39.2\% of total respondents have ICS/Intermediate as their level of education, $11.1 \%$ of total the respondents have Diploma as their educational qualification, 36.6\% have B.A. as their educational qualification \& 13.1\% have other like Matric, F.A and LLB as their level of educational qualification. 98.4\% of total respondents are of Constable Rank, 0.7 of total the respondents are of Sub-Inspector Rank \& $0.7 \%$ are of Inspector Rank.

\subsection{Reliability of a Scale}

Reliability shows the extent to which a measure is free from bias or errors. Cronbach Alpha scores measures the extent of consistency of results at different times (J.Cronbach, 1951). The most commonly used statistics is Cronbach's Alpha Coefficient. The value of Cronbach's coefficient lies between o \& 1. According to (Mallery, 2003) if the value of Cronbach Alpha coefficient is above 0.9 it is considered to be outstanding internal reliability, if value is above 0.8 it indicates a good internal reliability, value above 0.7 indicates a satisfactory internal reliability but the value of Cronbach Alpha below 0.5 is considered to be unacceptable. Results of reliability analysis are given in Table 1 below: 


\section{TABle 1: CRONBACH's AlPHA COEFFICIENT}

\begin{tabular}{|l|l|l|}
\hline Variable Name & No of Items & Cronbach's Alpha Value \\
\hline Working Conditions & 5 & 0.743 \\
\hline Growth Opportunities & 4 & 0.813 \\
\hline Peer/Fellow Relationship & 5 & 0.748 \\
\hline Work Itself & 5 & 0.737 \\
\hline Recognition & 4 & 0.746 \\
\hline Supervisor Relationship & 4 & 0.860 \\
\hline Salary & 4 & 0.746 \\
\hline Organizational Policies & 4 & 0.804 \\
\hline Motivation & 9 & 0.779 \\
\hline
\end{tabular}

According to Table 1 value of Cronbach's Alpha for Supervisor's Relationship, Growth Opportunities and Organizational Policies in above 0.8 which indicates good internal reliability whereas values of Cronbach's Alpha Coefficient for all other variables is above 0.7 which indicates satisfactory internal reliability.

\subsection{Correlation Analysis:}

Correlation Analysis is used to describe the strength and direction of relationship between two variables. Pearson Correlation Coefficient " $r$ " is used to measure the strength and the direction of relationship between two continuous variables (Pearson, 1930). According to (Monica Franzese, 2019), the value of " $r$ " varies from -1 to +1 . The value of $r<0$ indicates a negatives correlation (higher levels of one variable results in lower level of other variable) while the value of $r>0$ indicates a positive correlation (higher levels of one variable are linked to higher level of other variables). The value of $r=0$ indicates no correlation. The sign associated with value of " $r$ " indicates the direction of correlation. When the value of $r=+1$ it indicates a perfect correlation (increase in one variable results in a proportional increase in other variable) while $r=0$ indicates no relation at all and $r=-1$ indicates a perfect negative correlation. (Increase in one variable causes a proportional decrease in other variable). Values of correlation analysis are presented in Table 2. 
TABLE 2: CORRELATION ANALYSIS

\begin{tabular}{|c|c|c|c|c|c|c|c|c|c|c|}
\hline Sr. No. & Variables & 1 & 2 & 3 & 4 & 5 & 6 & 7 & 8 & 9 \\
\hline 1 & $\begin{array}{l}\text { Working } \\
\text { Conditions }\end{array}$ & 1 & & & & & & & & \\
\hline 2 & $\begin{array}{l}\text { Career } \\
\text { Growth } \\
\text { Opportuni } \\
\text { ties }\end{array}$ & $.535^{* *}$ & 1 & & & & & & & \\
\hline 3 & $\begin{array}{l}\text { Peer/Fello } \\
\text { w } \\
\text { Relationsh } \\
\text { ips }\end{array}$ & $.450^{* *}$ & $.511^{* \star}$ & 1 & & & & & & \\
\hline 4 & $\begin{array}{l}\text { Work } \\
\text { Itself }\end{array}$ & $.119^{*}$ & $.181^{* *}$ & $.212^{* *}$ & 1 & & & & & \\
\hline 5 & $\begin{array}{l}\text { Recognitio } \\
\mathrm{n}\end{array}$ & $.236^{* *}$ & $.257^{* *}$ & .086 & $.234^{* *}$ & 1 & & & & \\
\hline 6 & $\begin{array}{l}\text { Supervisor } \\
\text { Role }\end{array}$ & $.324^{* *}$ & $.438^{* *}$ & $.249^{* *}$ & $.251^{* *}$ & $.384^{* *}$ & 1 & & & \\
\hline 7 & Salary & .060 & $.292^{* *}$ & $.300^{* *}$ & .055 & .085 & $.214^{* *}$ & 1 & & \\
\hline 8 & $\begin{array}{l}\text { Organizati } \\
\text { onal } \\
\text { Policies }\end{array}$ & $.537^{* *}$ & $.491^{* *}$ & $.400^{* *}$ & $.157^{* *}$ & $.272^{* *}$ & $.451^{* *}$ & $.224^{* *}$ & 1 & \\
\hline 9 & Motivation & $.672^{* *}$ & $.612^{* *}$ & $.647^{* *}$ & $.146^{*}$ & $.214^{* *}$ & $.433^{* *}$ & $.354^{* *}$ & $.733^{* *}$ & 1 \\
\hline
\end{tabular}

From the result of presented in Table 2 following conclusions can be drawn:

- The value of " $\mathrm{r}$ " is positive means there is a correlation

- There is a strong positive relationship between Working Conditions (WC), Growth Opportunities (GO), Fellow Relationship (FR), Organizational Policies \& Motivation having values of "r" 0.672 , $0.612,0.642$ and 0.733 respectively.

- There is a moderate relationship between Supervisor Role (SR), Salary (S) \& Motivation having values of " $r$ " 0.433 and 0.354 respectively

- There is a weak relationship between Work Itself (WI), Recognition (R) \& Motivation having values of "r" 0.146 and 0.214 respectively

\subsection{Hypothesis Testing}

Multiple Regression Analysis is used for testing hypothesis. Multiple Regression Analysis is a multivariate technique means it is used when multiple independent variables are used to predict variance in a single dependent variable (Uma Sekaran, 2016). Multiple regression analysis gives 
statistical significance "p" of the model (value of $\mathrm{p}<0.05$, indicates a model is statistically significant. The results are presented in Table 3.

TABLE 3: ANOVA TABLE

\begin{tabular}{|c|c|c|c|c|c|c|}
\hline \multicolumn{7}{|c|}{ ANOVA $^{\mathrm{a}}$} \\
\hline \multicolumn{2}{|c|}{ Model } & Sum of Squares & Df & Mean Square & $\mathrm{F}$ & Sig. \\
\hline \multirow[t]{3}{*}{1} & Regression & $144 \cdot 445$ & 8 & 18.056 & 120.158 & $.000^{\mathrm{b}}$ \\
\hline & Residual & 44.629 & 297 & .150 & & \\
\hline & Total & 189.074 & 305 & & & \\
\hline \multicolumn{7}{|c|}{ a. Dependent Variable: Motivation } \\
\hline \multicolumn{7}{|c|}{ b. Predictors: (Constant), OP, WI, S, R, FR, SR, WC, GO } \\
\hline
\end{tabular}

According to results shown in Table 3 value of $\mathrm{p}<0.05$ which indicates that model is statistically significant. Apart from determining statistical significance, multiple regression is also used to forecast the effects of impacts of changes i.e. how dependent variable is changed or impacted with change in independent variables. Adjusted $\mathrm{R}^{2}$ known as coefficient of determination is used to study the impact. Value of $\mathrm{R}^{2}$ varies between $\mathrm{O}$ and 1 with $\mathrm{o}$ indicating no correlation, 1 indicating a perfect correlation. Results are presented in Table 4 .

TABLE 4: REgRESSION MODEl Summary

\begin{tabular}{|c|c|c|c|c|c|}
\hline \multicolumn{6}{|c|}{ Model Summary $^{b}$} \\
\hline Model & $\mathrm{R}$ & R Square & Adjusted R Square & $\begin{array}{c}\text { Std. Error of the } \\
\text { Estimate }\end{array}$ & Durbin-Watson \\
\hline 1 & $.874^{\mathrm{a}}$ & .764 & .758 & .388 & 1.715 \\
\hline
\end{tabular}

a. Predictors: (Constant), OP, WI, S, R, FR, SR, WC, GO;

b. Dependent Variable: Motivation

Here we have to consider Adjusted $\mathrm{R}$ Square value. The Table 04 shows Adjusted $\mathrm{R}^{2}$ value of $0.758\left(0.758^{*} 100=75.8 \%\right)$. The above value suggests that $75.8 \%$ variance in dependent variable i.e. Motivation is explained by Independent Variables i.e. Working Conditions, Growth Opportunities etc. Regression coefficient " $\beta$ " determines the impact of each independent variable on dependent variable. The results are presented below in Table 5 . 
TABLE 5: COEFFICIENT TABLE OF REgRESSION MODEL

\begin{tabular}{|c|c|c|c|c|c|c|c|c|c|}
\hline \multicolumn{9}{|c|}{ Coefficients $^{\mathrm{a}}$} & \multirow{3}{*}{$\begin{array}{l}\text { Hypothesis } \\
\text { Decision }\end{array}$} \\
\hline \multirow{2}{*}{\multicolumn{2}{|c|}{ Model }} & \multicolumn{2}{|c|}{$\begin{array}{c}\text { Unstandardized } \\
\text { Coefficients }\end{array}$} & \multirow{2}{*}{$\begin{array}{c}\text { Standardiz } \\
\text { ed } \\
\text { Coefficient } \\
\text { s } \\
\\
\text { Beta } \\
\end{array}$} & \multirow[b]{2}{*}{$\mathrm{t}$} & \multirow[b]{2}{*}{ Sig. } & \multicolumn{2}{|c|}{$\begin{array}{c}\text { Collinearity } \\
\text { Statistics }\end{array}$} & \\
\hline & & B & $\begin{array}{l}\text { Std. } \\
\text { Error }\end{array}$ & & & & Tolerance & VIF & \\
\hline \multirow[t]{9}{*}{1} & (Constant) & .024 & .147 & & .161 & .872 & & & \\
\hline & WC & .240 & .032 & .278 & 7.402 & .000 & .563 & 1.777 & Supported \\
\hline & GO & .061 & .030 & .078 & 2.033 & .043 & .534 & 1.874 & Supported \\
\hline & FR & .284 & .036 & .282 & 7.938 & .000 & .630 & 1.586 & Supported \\
\hline & WI & -.035 & .028 & -.037 & -1.237 & .217 & .886 & 1.129 & Not Supported \\
\hline & $\mathrm{R}$ & -.020 & .025 & -.026 & -.818 & .414 & .803 & 1.245 & Not Supported \\
\hline & SR & .038 & .025 & .052 & 1.507 & .133 & .660 & 1.515 & Not Supported \\
\hline & $S$ & .115 & .026 & .135 & $4 \cdot 392$ & .000 & .835 & 1.198 & Supported \\
\hline & $\mathrm{OP}$ & .305 & .029 & .392 & 10.616 & .000 & .584 & 1.712 & Supported \\
\hline \multicolumn{9}{|c|}{$\begin{array}{l}\text { a. Dependent Variable: Motivation } \\
\text { Note: WC: Working Conditions;GO:Growth Opportunities;FR:Fellow } \\
\text { Relationships;WI:Work Itself;R:Recognition;SR:Supervisor } \\
\text { Relationship;S:Salary;OP:Organizational Policies; }\end{array}$} & \\
\hline
\end{tabular}

\section{Discussion}

The results of analysis presented in Table 4 indicate that five out of eight hypothesis are accepted while three hypothesis are rejected based on value of regression coefficient " $\beta$ ". Working conditions, growth opportunities, peer/fellow relationship, salary and organizational policies are among motivational factors while work itself, recognition and supervisor's role don't have impact on motivation of respondents.

Organizational Policies is the top motivational factor with value of $\beta=0.392$ (in other words $39.2 \%$ variation in dependent variable motivation is caused by organizational policies). The current findings are in line with previous studies conducted by (Saraswathi, 2011) on IT and Non-IT workers, (Bandyopadhay, 2014) study on government doctors in India. Similarly, a senior police officer (Imam, 2011) also considers organizational role essential for motivation of police force.

Fellow/peer relationship is among the motivational factors with value of $\beta=0.282$ (in other words $28.2 \%$ variation in dependent variable motivation is caused by fellow/peer relationships). The nature of police works involves a lot of stress so interpersonal relationships can certainly help employees in overcoming the work born stress. A study on Indian Police force by (Gupta, 2002) reports interpersonal relationship to have a significant impact on motivation of police force. A study conducted on banking sector of Pakistan by (Ismail Khan, 2013) also reports coworkers a motivational factor to have a significant impact on motivation of employees. A study conducted on Indian Police force by (Lokesh, 2016), also reports interpersonal relationship as factor that enhances motivation of police force.

Working condition are a motivational factor with $\beta=0.278$ (in other words $27.8 \%$ variation in dependent variable motivation is caused by working conditions). Good working conditions will certainly 
foster a sense of motivation of employees. According to a study conducted by (Shalini Bhatia, 2014), on Government Doctors in India, adequate working conditions was among top motivational factors. Similar findings have been reported by (Sommerfeldt, 2010), in his study on Queensland Police force. (Saraswathi, 2011), in his study also reported similar findings. A study on Indian Police force by (Lokesh, 2016) also reports wanting or poor working conditions as a factor that results in dissatisfaction of employees.

Salary is also among the motivational factors with a value of $\beta=0.135$ (in other words $13.5 \%$ variation in dependent variable motivation is caused by salary. The nature of police duties though most complex and demanding yet it is among the least paid jobs in Pakistan. Senior police officer (Imam, 2011) says adequate salary is a factor that can motivate employees. In their study on motivation of employees (Ashfaq Ahmed, 2009) conclude adequate salary to have a significant impact on motivation of employees. Similar findings have also been reported by (Barisua Ernest, 2015) in their study on Nigerian Police force.

Career/Growth opportunities is another motivational factor reported by respondents and according to Table $4 \beta=0.078$ (in other words $7.8 \%$ variation in dependent variable motivation is caused by career/growth opportunities). The presence of adequate growth opportunities create a sense of job security among employees which leads to job satisfaction and ultimately employees feel motivated. Study by (Shafighi, 2013) on motivation of employees indicates that presence of chances to grow keeps employees motivated. The job context factors (characteristics of organization) are considered as a source of stress in policing (Shane, 2010). Chances of promotion is considered as job context factors and absence of adequate chances of promotion may result in stress which demotivates police force at work (Yanan Wang, 2014).

Factors like recognition, work itself and supervisor's role that are considered as motivational factors by literature were not proven statistically significant. The rejection of these hypothesis strengthens the notion that motivation is a complex phenomenon and sources of motivation tend to differ from people to people. In a study on Malaysian service industry by (Muhammad Saeed Aarabi, 2013) indicates work itself has no impact on motivation of employees. Recognition was not reported among top motivational factors by (Saraswathi, 2011) in his study.

\section{Conclusion, Recommendation and Future Research:}

Police Department is among few organizations of today's era which are heavily dependent on the skills and abilities of humans and motivation is an important management tool in such organizations (Gupta, 2002). Motivated employees are certainly an asset for any organization and as far as law enforcement agencies are concerned, motivation is an important tool to overcome work born stress. The identified factors should be taken into consideration by the higher management while devising policies. Proper job and promotion structure should be devised so that employees feel job security and thus perform their duty efficiently. Adequate facilities are essential for motivation of police force (Imam, 2011). Management should take steps to provide basic health, education and accommodation facilities to employees. Similarly police is among the lowest paid jobs when compared with the complexity of work. Adequate salaries including rewards and other benefits should be provided to employees to keep them motivated.

If we compare the motivational factors identified by current study with different theories of motivation we can conclude that external factors or hygiene factors indicated by (Frederick Herzberg, 1959) and lower level needs indicated by (Maslow, 1943) like working conditions, peer/fellow 
relationships, salary and organizational policies are among top motivational factors. The dominance of extrinsic motivational factors/hygiene factors indicate that management need to focus on fulfilling basic level needs to keep employees satisfied which will enhance their motivation.

In Pakistan, research culture is not so prevalent in public sector organizations, therefore seeking permission for conducting research was a cumbersome task. As no such activity was conducted before so respondents were not much aware of the whole activity which resulted in delays. The police management should make efforts to create research supportive environment within the department. This will make management well aware of the needs of the force and will help achieve the desired efficiency.

Future research should examine a greater research sample compared to current research that was primarily focused on Lahore based force due to time and other constraints. Some additional motivational factors may be studied. The current study is limited to identification of motivational factors and their impact on overall motivation. The study can be further enhanced to study how motivation impacts performance of employees.

\section{References}

(n.d.). Retrieved from International Labor Organization: https://www.ilo.org/global/topics/workingconditions/lang--en/index.htm

Abdul Qayyum Chaudry, H. J. (2012). The impact of Transformational and Transactional Leadership Styles on Motivation of Employees in Pakistan. Pakistan Economic and Social Review, 222-231.

Alderfer, C. P. (1969). An empirical test of a new theory of human needs. Organizational Behavior and Human Performance, 142-175.

AlKahtani et al. (2020). Impact of employee empowerment on organizational commitment through job satisfaction in four and five stars hotel industry. Management Science Letters, 813-822.

Altindis, S. (2011). Job motivation and organizational ommitment among the health professionals: A questionnaire survey. African Journal of Business Management.

Ashfaq Ahmed, Z. A. (2009). ROLE OF NON-FINANCIAL BENEFITS ON MOTIVATION OF EMPLOYEES. Comparing Methods of estimation in experimental design (pp. 115-125). Lahore: Islamic Countries Society of Statistical Sciences.

Asif Sajjad, H. G. (2013). Impact of Motivation on Employee Turnover in Telecom Sector of Pakistan. Journal of Business Studies , 76-92.

Bandyopadhay, B. P. (2014). Beyond job security and money: driving factors of motivation of government doctors in India. Human Resources for Health.

Barisua Ernest, N. a. (2015). A QUANTITATIVE STUDY OF CORRELATES OF JOB SATISFACTION AMONG OFFICERS OF NIGERIA POLICE. Journal of Social Sciences \& Humanities Research, 1-8.

David J. Weiss, R. V. (1967). Manual for the Minnesota Satisfaction Questionnaire. Minnesota: Vocational Rehabilitation Administration.

Farhat Ullah, I. A. (2016). Motivational aspects in Police Basic Training to Counter Terrorism in KPK. Pakistan Journal of Criminology, 57-73.

Farhat Ullah, S. H. (2016). Factors Influencing Police Image in Public. Pakistan Journal of Criminology, 134-138.

Frederick Herzberg, B. M. (1959). The Motivation to Work. New York: John Willey and Sons.

Gupta, N. J. (2002). Analysing the Motivational needs amongst Policemen: Maslow's Theory Revisited. The Police Journal.

H.Room, V. (1964). Work and Motivation. New York: Wiley.

H.Vroom, V. (1964). Work and Motivation. New York: Wiley. 
Haider, \& Kayani. (2020). The impact of customer knowledge management capability on project performance-mediating role of strategic agility. Journal of Knowledge Management.

Herzberg, F. (2003). One More Time: How Do You Motivate Employees ? Boston: Harvard Business School Publishing Corporation.

Imam, D. S. (2011). Police and the Rule of Law in Pakistan: A Historical Analysis. Barkeley Journal of Social Science.

Iqbal et al. . (2020). Comparative Analysis of Effective Project Governance Practices and Benefit Realization Management for the Successful Execution of Projects in NGO Industry. Journal of Accounting and Finance in Emerging Economies, 923-935.

Ismail Khan, M. S. (2013). INFLUENCE OF INTRINSIC AND EXTRINSIC REWARDS ON EMPLOYEE PERFORMANCE: THE BANKING SECTOR OF PAKISTAN. Academic Research International, 282291.

J.Cronbach, L. (1951). Coefficient Alpha and the internal structure of tests. Psychometrika, 294-334.

Joshi, M. (2013). Human Resource Management . Bookboon.

Lokesh, S. P. (2016). Job Satisfaction among police personnel: A Socio-Demographic Study. Global Journal of Interdisciplinary Social Sciences, 54-62.

Mallery, D. G. (2003). SPSS for Windows Step by Step: A simple Guide and Reference, 11 Update (4th Ediiton). Allyn \& Bacon.

Maslow, A. H. (1943). A Theory of Human Motivation.

McClelland, D. C. (1961). The Achieving Society. Princeton, N.J., Van Nostrand.

Monica Franzese, A. I. (2019). Encyclopedia of Bioinformatics and Computational Biology. Rome, Italy: Academy Press. doi:https://doi.org/10.1016/B978-0-12-809633-8.20358-o

Muhammad Asad Khan, A. H. (2020). Effect of Performance Appraisal on Employees' Satisfaction: A Case Study of University of Peshawar, Khyber Pakhtunkhwa, Pakistan. Review of Applied Management and Social Sciences, 131-140. Retrieved from http://ramss.spcrd.org/index.php/ramss/article/view/40/33

Muhammad Saeed Aarabi, I. D. (2013). Relationship between Motivational Factors and Job Performance of Employees in Malaysian Service Industry. Asian Social Science.

Pearson, K. (1930). The Life, Letters and Labors of Francis Galton. Cambridge University Press .

Pervez, R. P. (2014). A Counterterrorism Role for Pakistan's Police Stations. Washington DC: United States Institute of Peace .

Punjab Police Government of Punjab. (n.d.). Retrieved from Punjab Police: https://punjabpolice.gov.pk/

Saraswathi, D. S. (2011). A STUDY ON FACTORS THAT MOTIVATE IT AND NON-IT SECTOR EMPLOYEES: A COMPARISON. International Journal of Research in Computer Application and Management, 72-77.

Shafighi, M. A. (2013). The Effect of Work Motivation on Employees' Job Performance. International Journal of Academic Research in Business and Social Sciences.

Shalini Bhatia, B. P. (2014). What Motivates Government Doctors in India to Perform Better in their Job? Journal of Health Management, 149-159.

Shane, J. M. (2010). Organizational stressors and police performance. Journal of Criminal Science, 807818.

Sommerfeldt, V. (2010). AN IDENTIFICATION OF FACTORS INFLUENCING POLICE WORK PLACE MOTIVATION. Queensland.

Tulloch, L. N. (2008). Incentives for retaining and motivating health workers in Pacific and Asian Countries . Human Resource for Health, 6-18.

Uma Sekaran, R. B. (2016). Research Methods For Business: A Skill Building Approach, 7th Edition. John Willey and Sons.

Were M. Susan, P. R. (2012). Influence of Motivation on Performance in the Public Security Sector with 
a Focus. International Journal of Business and Social Science.

Whisenand, P. M. (1998). Supervising Police Personnel. The fifteen responsibilities. New Jersey: Prentice Hall.

Yanan Wang, L. Z. (2014). Stress, Burnout, and Job Satisfaction: Case of PoliceForce in China. Public Personnel Management, 1-15. 